\title{
Interest Group Politics in the New South
}

\author{
Clive S. Thomas, University of Alaska Southeast \\ Ronald J. Hrebenar, University of Utah
}

In this study, a consistent mix of quantitative and qualitative methods is applied to the study of the interest group systems of twelve southern states. It is found that recent transformations of southern life and politics have affected surface aspects of southern interest group systems, such as the range of interests represented and the style of representation, but have not altered the fundamental dominance of the policy process by traditional economic and institutional interests that enjoy advantages in the resources of influence. Existing theories of an inverse relationship between interest group power and party development, socioeconomic development, and government professionalization, respectively, are thus thrown into question.

The literature on Southern politics far outstrips that for any other region of the United States. Yet, this literature includes no study, comprehensive or otherwise, of the special role of interest groups in southern politics. Such a study is necessary for two reasons.

First, the enduring nature of various entrenched interest groups has provided political stability by filling several political voids that are the concomitants of weak state parties, factionalism, unstable leadership, and rapid change and flux at the systemic level. Southern interest groups have fulfilled political functions that in many states are the province of parties, leaders, and public officials, as well as of interests. These functions include, but are not limited to, the recruitment of candidates, financing of campaigns, and the determination and implementation of public policies.

Second, this stabilizing, quasi-public role of southern interest groups, together with the ease of amendment of southern state constitutions, has resulted in their exertion of enormous influence upon the policy-making processes of all southern states. Together, these two factors have meant that in most southern states, interest groups have been more important to the functioning of the political and governmental systems, and thus more powerful within them, than in all but a few states in the nation.

Yet, in virtually all comparative studies of southern politics, interest groups are treated only incidentally, while the dominant themes of such studies tend to be the politics of race, the increased political participation of blacks, the effects of economic growth, population shift, and demographic change, the rise of the Republican party, factions within the Democratic party, and the impact of the South in 
national politics (see, e.g., Havard 1972; Bass \& DeVries 1976; Lawson 1976; Ball, Krane, and Lauth 1982; Lamis 1984; Black and Black 1987; Stanley 1989). To focus upon southern interest groups, then, is to provide a different as well as necessary perspective on the politics of the South and its individual states.

Two themes about contemporary interest group activity in the South are recurrent in the above literature. One is that great changes have occurred within interest group politics in all southern states during the past quarter-century. These changes reflect, and to a large extent engendered, the transformation of southern politics that has taken place during that period. The second holds that many traditions still linger on within southern interest group politics. This, too, is a reflection upon the recent transformation of southern politics: the social and political upheavals of the recent past are held to have affected some aspects of the status quo ante -- namely, the formally-constituted institutions of representative democracy -- much more than others. Interest groups, as inherently private associations that enjoy First Amendment protection despite their assumption of certain quasi-public roles, are among those less affected.

Besides sifting for evidence of these two theses, this study has two other purposes. One is to identify the prevailing characteristics of southern interest groups with regard to types of groups that are active, lobbying, group power, and group tactics. The other is to assess the differences between the interest group systems in the South and those in other regions of the country. All four themes are assayed in the context of a common analytical framework for examining interest group activity. ${ }^{1}$

\section{Existing Research on State Interest Groups}

Since the first major research by Bentley (1908) and Truman (1951), the study of interest groups and their impact on public policy in the United States has focused predominantly on national organizations and their activities in Washington, D.C. Thus, all of the states, including the twelve southern states examined here, exist and operate in an informational void about the nature of their interest group systems.

Six types of studies have touched on some aspects of interest group activity in the South. First, there is some consideration of interest groups in texts on the government and politics of individual southern states (e.g., Blair 1988). Such treatments range from the 
anecdotal and unmethodical to the highly conceptual and quantitative. Second, beginning with V.O. Key (1949), interest groups have received some attention in general texts on Southern politics. None, however, has analyzed the role that groups have played over time in southern state political systems. Third, recent literature on specific aspects of Southern politics, such as those produced by the Citadel group (Steed, et al. 1980,1986, 1989), have included treatments of particular interest groups in the South. A fourth category consists of the small body of public policy literature, such as Zeigler's (1963) study of the Florida Milk Commission and Stewart and Sheffield's (1987) study of black groups' use of the courts in Mississippi, that has taken the case-study approach to examining the impact of groups. A fifth type of literature consists of micro-analyses of specific aspects of the internal organization or operation of groups, or how they affect one specific aspect of the policy process. Such studies may be state-specific case studies, as was Dunn and Whistler's (1987) study of Arkansas lobbyists, or may use one or more southern states as part of a larger study, as did Zeigler and Baer's (1969) lobbying piece and Bell, Hamm, and Wiggins' (1985) study of groups' impact on certain policy areas.

Although useful contributions to the study of southern interest groups, the foregoing studies are of very limited value for purposes of comparative analysis because of their divergent foci, scope, and methods. There is, however, a sixth category of literature that has been comparative in focus and has included the southern states as part of nation-wide studies of state interest group activity. These macrostudies have attempted to understand interest groups in the context of the individual states, and particularly in relation to their political and governmental systems. The most notable work here is that of Zeller (1954), Zeigler (1983), Zeigler and Van Dalen (1976), and Morehouse (1981). None of these, however, conducted truly systematic research on all of the southern states. Their analyses were based on original data from only a few states, and drew upon other sources that varied methodologically from the highly quantitative to the impressionistic. Thus, the theories, propositions, and conclusions of these studies are heavily dependent upon secondary sources, and sometimes upon extrapolation or speculation.

Yet each became a major source for the evaluation of interest groups at the sub-national level at a time when few other data existed. Zeller (1954) was the first to categorize states as having strong, moderate, or weak interest group systems. Zeigler (1983) and Zeigler and 
Van Dalen (1976) developed several theories and propositions about how the economic, social, and political systems in a state influence the composition, power, and operation of the state's interest group system, highlighted the relationship between political party strength and interest group power, and developed a quadripartite classification of group power within strong interest group states. Morehouse (1981) has built on this work by expanding on the relationship between party strength and group strength, refining the tripartite classification of state interest group systems, and developing the first "power list" of the most significant groups in each of the fifty states. These contributions have served as benchmarks for subsequent research, and provide this study with a point of departure.

\section{Data and Definitions}

The data used in this study are taken from the joint study of interest groups in all fifty states that was coordinated by Hrebenar and Thomas (1990). ${ }^{2}$ Pre-1980 data on interest groups in the South, defined here as the eleven states of the Confederacy plus Kentucky, has been taken from the state-specific studies written by the members of that study, as well as from previous works. ${ }^{3}$

The core of the methodology used in these studies was a set of guidelines that required each researcher to investigate a common set of questions about such topics as the types of groups active, the tactics that they use, the make-up of the lobbying community (and recent changes therein), and group power within the state policy-making process (for individual groups and for the interest group system as a whole). Each investigator used a set of common definitions of terms and a set of five common survey instruments for use with legislators, legislative staffers, lobbyists, administrators, and members of the press. ${ }^{4}$ This shared methodology provided a consistent fund of information that facilitated comparative analysis. Investigators also were asked to gather as much empirical data as possible about lobbying registration and expenditures, including political action committee data, from appropriate state monitoring agencies. These data helped to delineate trends in these areas, although comparison remained difficult because regulations for registration and reporting of lobbying activities and expenditures vary considerably among the states. Finally, each investigator also was asked to identify ways in which their state's interest group system fit or diverged from existing theories of interest group activity in the states (as developed by Zeller, Zeigler, and Morehouse). In the latter case, they were 
asked to offer alternative explanations for their state.

A major element of the methodology was the use of common definitions of interest group, interest, lobby, lobbyist, and group power. Here we will define the first four concepts, and leave group power until a later section. We defined interest group broadly in order to include the so-called "hidden groups," particularly government agencies. Our definition is any association of individuals or organizations, formally organized or not, that attempts to influence public policy. The Virginia Trucking Association (VTA) is an example. Although an interest group such as the VTA is a specific organization, the members of this organization are also part of the broader transportation interest, which includes bus companies, air carriers, railroads, and petroleum suppliers. Truckers are also part of the still broader Virginia business lobby, which includes all groups and organizations -- such as oil and gas companies, bankers, retailers, hoteliers, and a host of others -- interested in promoting conditions favorable to business operations. On occasion, however, groups belonging to a shared interest or lobby might find themselves on opposite sides of a political issue. This could be the case if the VTA sought higher state weight limits for trucks, which the railroads might oppose out of fear that such an increase could reduce the volume of rail shipping. Although it is difficult to distinguish where interest groups, interests, and lobbies begin and end, respectively, such distinctions are necessary for analytical purposes.

Finally, we defined a lobbyist as a person designated by an interest group to represent it to government for the purpose of influencing public policy in that group's favor. The previous paragraph gives us to understand that those represented by a lobbyist need not necessarily be a formal organization, such as the VTA. The definition includes informal and ad hoc groups, such as union members disaffected from their leaders, or an informal association of business people, or even an individual representing only him or herself in the pursuit of some heartfelt cause.

\section{Similarities and Differences in Southern Interest Group Systems: An Analytical Framework}

As various social and economic factors change in a state, so will its politics and government and its interest group system--all are inextricably bound together. Also, while interest groups are very important in the politics of all states, and particularly the southern states, there is 
variation--and in some instances considerable variation--in the makeup and operation of state interest group systems. Those in coastal megastates, such as Texas and Florida, for instance, are more developed and diverse than those in hinterland areas such as Arkansas and Kentucky.

A problem besetting the study of state interest groups has been the lack of a common analytical framework for studying the development of groups within individual states. While some theories exist for explaining variations among state interest group systems, no comprehensive framework exists for the analysis of the types of groups existent at any particular time, the tactics that they use, and the power that they exert. From our research we have attempted to develop such an analytical framework, which is set out in Figure 1.

The eight factors and their components in Figure 1 are interrelated. A change in one may reflect or lead to a change in one or more of the other factors. Any change at all is likely to affect the nature of group activity; and major changes will have a significant impact upon the interest group and lobbying context in a particular state, or in the states collectively. Equipped with information about these eight factors, we can better understand the development, role, and effectiveness of interest groups, interests, and lobbies in southern politics.

The eight factors and their components in Figure 1 are interrelated. A change in one may reflect or lead to a change in one or more of the other factors. Any change at all is likely to affect the nature of group activity; and major changes will have a significant impact upon the interest group and lobbying context in a particular state, or in the states collectively. Equipped with information about these eight factors, we can better understand the development, role, and effectiveness of interest groups, interests, and lobbies in southern politics.

\section{The Old Style Southern Interest Group System and the Roots of Its Transformation}

Until the 1950s, the interest group system in the southern states was narrow as far as the types of interests represented, and narrower still in the sense of which ones wielded power. Until the postwar period, the economies of all southern states were heavily dependent upon agriculture. Thus, agricultural groups, especially planters and other large landowners, were very prominent. Also, because of the importance of the small town in such an agrarian society, local elites, 
FIGURE 1.

Eight Factors Influencing the Make-up, Operating Techniques and Impact of Interest Group Systems in the States

1. State Policy Domain: Constitutional/legal authority of a state affects which groups will be politically active. Policies actually exercised by a state affect which groups will be most active. The policy priorities of a state will affect which groups are most influential.

2. Intergovernmental Spending and Policy Making Authority: The greater federal devolution of policy and funding responsibilities, the greater the centralization of policy making in the state capital, vis-a-vis local governments; and the higher the percentage of state versus local spending on individual programs and services, the more intense will be lobbying in the state capital. This increased group activity in the states may have the effect of making both individual interest groups and group systems more significant and powerful in state politics.

3. Political Attitudes: Especially political culture, and political ideology viewed in terms of conservative/liberal attitudes. Affects the type and extent of policies performed; the level of integration/fragmentation and professionalization of the policy making process; acceptable lobbying techniques; and the comprehensiveness and stringency of enforcement of public disclosure laws, including lobby laws.

4. Level of Integration/Fragmentation of the Policy Process: Strength of political parties; power of the governor; number of directly elected cabinet members; number of independent boards and commissions; initiative, referendum and recall. Influences the number of options available to groups: greater integration decreases them, while more fragmentation increases the options.

5. Level of Professionalization of State Government: State legislators, support services, bureaucracy, including the governor's staff. Impacts the extent to which public officials need group resources and information. Also affects the level of professionalization of the lobbying system.

6. Level of Socio-Economic Development: Increased socioeconomic diversity will tend to produce a more diverse and competitive group system; a decline in the dominance of one or an oligarchy of groups; new and more sophisticated techniques of lobbying such as an increase in contract lobbyists, lawyer-lobbyists, multi-client/multi-service lobbying firms, grassroots campaigns and public relations techniques; and a general rise in the professionalization of lobbyists and lobbying.

7. Extensiveness and Enforcement of Public Disclosure Laws: Including lobby laws, campaign finance laws, PAC regulations, and conflict of interest provisions. Increases public information about lobbying activities which has impacted the methods and techniques of lobbying, and in turn affects the power of certain groups and lobbyists.

8. Level of Campaign Costs and Sources of Support: As the proportion of group funding (especially from PACs) increases, group access and power increases.

Sources: Adapted for the South from Figure 4.1 in Thomas and Hrebenar (1990).

county courthouses, and local governments in general wielded considerable influence. Churches, especially the Baptists, also possessed political influence. In states host to a major industry, such as steel in Alabama, textiles in South Carolina, and the garment industry in Arkansas, industrial groups were important interests. But in about half of the southern states, large or even medium-sized industries were not among the significant interests. 
Within its narrow range of interests extant, the South was not dissimilar from most other states during the period. Until the 1950 s, the development of the interest group system in the South (and elsewhere in the nation) tended to follow an identifiable path. The railroads were an important, often dominant force in all southern states by the $1880 \mathrm{~s}$. Around the turn of the century, agricultural groups such as state Farm Bureaus and stockgrowers' and commodity associations began to develop a political voice in southern state capitals. From the mid-1930s on, these were joined by local government groups, labor unions, and education interests, especially school teachers. Together, these five interests--business, agriculture, labor, local government, and education --formed the major interests operating in state capitals of the South, and of the states in general, in the early 1960s.

Until very recently, one standard fixture of the state lobbying scene in the South and elsewhere was the stereotypical "wheelerdealer" style of lobbyist behavior. This style is easier to recognize than it is to define. But in general it refers to a powerful lobbyist who operates in an aggressive and flamboyant manner and is willing to use a variety of methods, some of which may be legally or morally suspect, to achieve goals. As with many other aspects of the pre-1960s lobbying community, it is impossible to determine how widespread this style was in the states. However, most investigators inferred that this was a prominent lobbying style in all of the states, particularly in the South, given the lack of legislative professionalism, the lack of public disclosure requirements, and the fact that the lobbyists' major task was to kill bills, not promote them.

As with many major changes in southern history, the major thrust that changed the politics of the South came from the outside. Change began to percolate during the 1940s and 1950s, but was not manifest until the 1960s. Of the many changes that took place, the most publicized, of course, were those wrought by the civil rights movement spearheaded by Martin Luther King, which led to federal action in the form of the Civil Rights Act of 1964 and the Voting Rights Act of 1965. But there were other changes as well, several of which were important to the transformation of the interest group system. In addition to the increased political participation of blacks and of lower-income whites brought about by the 1965 VRA, there was 1) the related rise of the Republican party and of two-party competition for national and statewide offices in most southern states, 2) increased economic diversity and decreasing dependence upon agriculture, 3) increasing urbaniza- 
tion accompanied by an increase in the middle class, 4) extensive reapportionment of state legislatures, and 5) increased demand for state and local government services, all of which culminated in an increased role for these governments. In short, the South underwent a major expansion of political pluralism. Interest groups both helped engender this expansion and in turn were affected by it. Whatever the causal relationship between groups and these changes, the result is that interest group politics in all southern capitals since then have been markedly different.

\section{Public Disclosure of Lobbying: Registered and Non-Registered Groups}

Full appreciation of contemporary interest group politics in the southern states and of the transformations it has undergone requires that one realize that the actual lobbying activity that takes place is much more extensive than an examination of public disclosure information about interest groups might lead us to believe. This is because several types of groups and interests are not required to register in the South. Consequently, as in all states, there are many non-registered or "hidden groups and lobbies" at work in southern state capitals.

The seventh factor of Figure 1 sets out the four types of provisions that help provide some public monitoring of interest group activity: lobby laws, conflict-of-interest provisions, campaign finance disclosure, and rules regulating the activities of PACs. While the first three types of laws existed in most southern states before the 1970s, they were usually weak and only loosely enforced. It took the Watergate affair of 1973-1974 to generate a reform movement across the nation in favor of more extensive and stringently enforced public disclosure. This movement also included the regulation of PACs which were burgeoning largely as a result of the simultaneous occurrence of declining parties, rising campaign costs, and the imposition of campaign contribution limits in many states. Although the South was touched by this postWatergate fervor, it was affected less so than regions such as the Upper Midwest and the Northeast.

Lobby laws provide the most specific and comprehensive information about interest group activity. Yet, these vary considerably in their inclusiveness, their reporting requirements, and the stringency with which they are enforced. This is the case both across the nation and within the South. In particular, differences in who is required and 
not required to register as a lobbyist under the various southern state laws produces a wide variance in the number of persons registering as lobbyists, as well as in the number of registrations of lobbying organizations (i.e., the employers or clients of lobbyists). Florida, for example, has perhaps the most comprehensive registrations in the nation, while Georgia has among the least comprehensive. But comprehensiveness does not guarantee stringency of enforcement. In general, the South, including Florida (Kelley and Taylor 1991), has the least stringently enforced lobby laws of any region in the nation.

The relative weakness of lobby laws in the South is explained by a combination of factors set out in Figure 1, including factors 4, 5, and 6, and particularly factor 3 . The traditionalistic political culture, although now disappearing in most parts of the region (Black and Black 1987), nevertheless bequeaths a legacy of non-intervention by government. The individualistic political culture that is now replacing traditionalism is also not particularly supportive of such restrictions. Then there is the fact that the power of some major interests has enabled them to forestall or weaken lobby law legislation. After years of legislative stalling and defeats, only in 1988 did Arkansas turn to the popular initiative to pass a comprehensive lobbying ethics law that included registration and reporting requirements (Blair 1988, 109-112).

As mentioned in our definitions, the largest of the non-registered or "hidden" lobbies in the states is government, particularly state agencies, boards, commissions, and local governments. Personnel employed by state universities as directors of governmental relations, or by municipalities as intergovernmental advisors, do not register as lobbyists in Arkansas, for example (although an attorney general's advisory opinion compels them to do so if liaison work is part of their job description and necessitates expenditures in excess of $\$ 250$ per quarter). Most consider certain Arkansas legislators who are also on the payroll of a state university or technical college (not to mention those employed by major private groups such as the state poultry federation and state contractors' and chiropractors' associations) to be lobbyists, as well. Because of the increasing growth of and reliance upon government, these are very significant lobbying forces in southern states, even those with diversified economies such as Florida and Virginia. Our research indicates that roughly 25 percent of the "lobbyists" working the halls of state government in the South on any given day represent government. Thus, to obtain an accurate picture of interest group activity in the South we cannot overlook government, even though the absence of records presents problems. 


\section{Interests Active in the Southern States Today}

Of all the transformations of interest group politics in the 12 southern states, the one that stands out the most is that, since the 1960s, interest group activity has expanded considerably in three regards. First, there has been a marked expansion in the number of groups seeking to influence state government. Second, the range of interests has expanded as new interests, such as social issue, public interest, and single issue groups have entered the political arena while other, more traditional interests have fragmented. Fragmentation has been particularly evident within the business and local government lobbies. Individual corporations or businesses, and individual cities and special districts (particularly school districts) have begun to lobby more as discrete, lone actors. They do so because although they may remain part of an umbrella organization, they regard their specific needs as less than fully met by the efforts of the umbrella group. Third, groups are lobbying more intensively than they did twenty or even ten years ago. They have more regular contact with public officials and use more sophisticated techniques. In states such as Mississippi and Virginia, this is partially the result of the legislature having moved from biennial to annual sessions.

Given the shortcomings of lobbying registration records, we used the definitions set out above to obtain an accurate picture of the range of groups and interests that operate in southern capitals today. This range is depicted in Table 1, which is organized on the basis of 1) the extent of an interest's presence in the twelve states, 2) whether they are continually or intermittently active, and 3 ) the intensity of their lobbying efforts. (Interests in each of the table's four cells are listed in descending order according to the estimated intensity of their lobbying efforts across the twelve states.)

As the first column indicates, well over half of the interests listed are present in all twelve states. Moreover, it is probably true to say that seventy-five percent of all lobbying efforts (in terms of time and money) are generated by the twenty interests in the continually active section of column one. Nevertheless, although not all are continually active or intense when active, a very broad range of interests, public and private, operates in southern states today.

The increasing prominence of several interests in column one is worthy of mention. In the governmental lobby category are individual cities and special local government districts (such as school dis- 


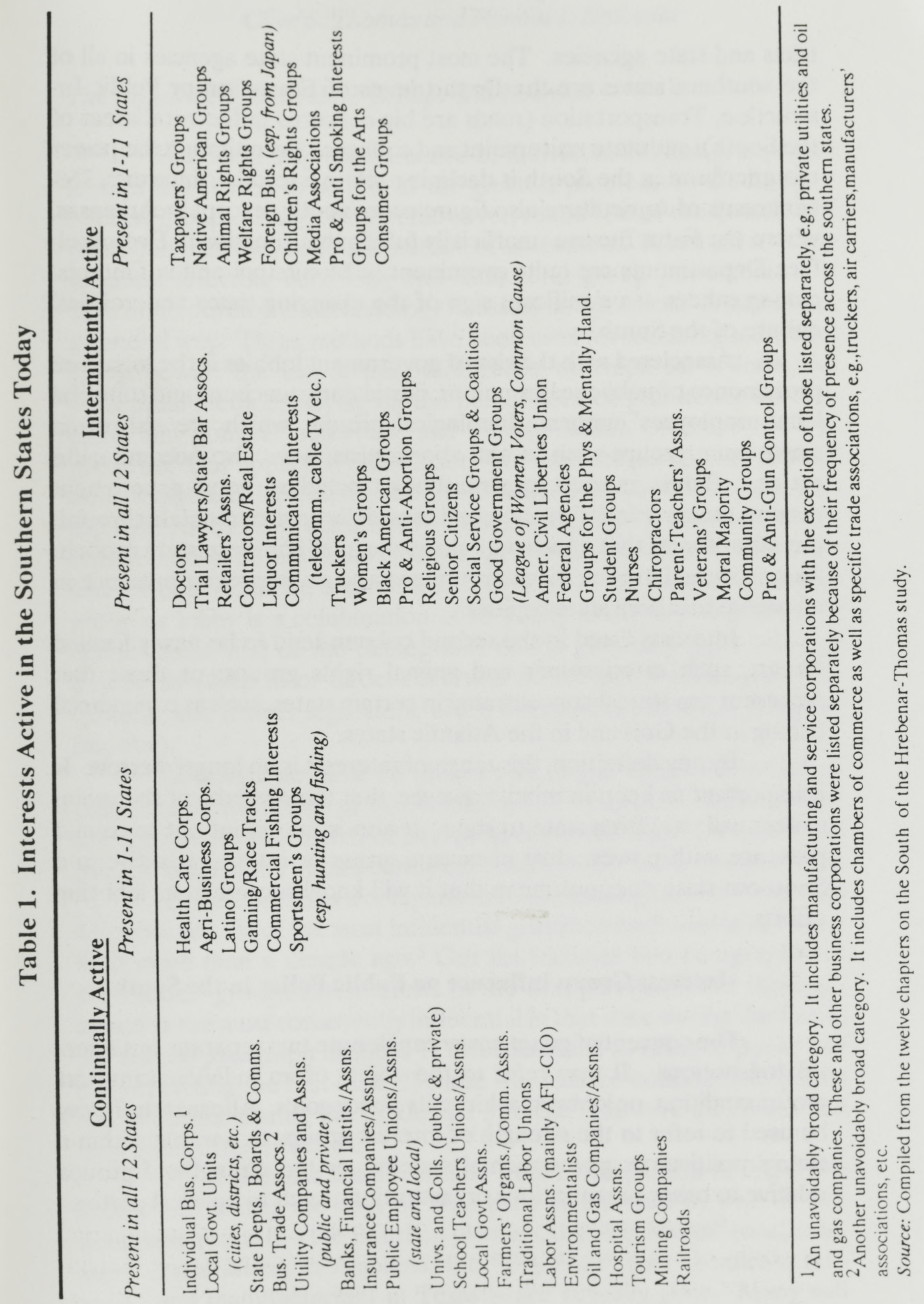


tricts and state agencies. The most prominent state agencies in all of the southern states are the Departments of Education or Public Instruction, Transportation (roads are big concerns in the rural areas of the South), and state universities and colleges. Even though the power of agriculture in the South is declining relative to other interests, Departments of Agriculture also figure prominently (except in Arkansas, where the Farm Bureau unofficially fulfills that function). Even Welfare Departments are quite prominent in Mississippi and in Georgia, among others -- a significant sign of the changing times and political culture of the South.

Associated with the rise of government lobbies is the increased prominence of public sector unions, particularly teachers' and state and local employees' unions. Ideological groups, which are also often single-issue groups such as anti-abortionists, have also become quite active. Public interest organizations, including good government groups, senior citizens' groups, and especially environmentalist groups, are other forces that now have a presence in all southern state capitals. As one should expect, black groups are also an important presence in all twelve southern state capitals.

Interests listed in the second column tend to be newly formed groups, such as consumer and animal rights groups; or those that represent an interest concentrated in certain states, such as commercial fishing in the Gulf and in the Atlantic states.

By any definition, this range of interests is no longer narrow. It is important to keep in mind, however, that the diversity of the group system will vary from state to state. It also is important not to equate presence with power. Just because a group or interest is active in a Southern state does not mean that it will know success in its lobbying efforts.

\section{Interest Group Influence on Public Policy in the South}

The concept of group power can denote two separate, but interrelated notions. It may refer to the ability of an individual interest group, coalition, or lobby to achieve its policy goals. Alternately, it may be used to refer to the strength of interest groups as a whole within a state's political or governmental systems, or the strength of groups relative to other organizations or institutions, such as political parties. 


\section{The Influence of Individual Groups and Interests}

Understanding the influence of individual interest groups and lobbies has proven to be one of the greatest problems in the study of interest groups. The problems, however, relate less to the question of definition than they do to the method of assessment. There are so many variables affecting both long and short-term group power that it is difficult to develop a methodology to assess and predict it in more than a general way. Three methods have been used for assessing individual group power: the use of purely objective or empirical criteria; the perceptual method, relying on the perceptions of politicians, bureaucrats, and political observers; and a combination of these two approaches. Our approach is the latter. We used the perceptual method but attempted to inject a high degree of objectivity and consistency into the research by using quantitative techniques to analyze the responses. Our definition of individual group power, which also incorporates our method of assessment, is as follows: the power of any particular interest group or lobby is a combination of its ability to achieve its goals as it defines them, and of the perceptions of the various people who are directly involved in or direct observers of the policy-making process (present and former legislators, aides, bureaucrats, lobbyists, journalists, etc.).

Although we have no illusions as to the definitive nature of either the methodology or the results, our findings do provide the first comprehensive assessment of interest group effectiveness in the South that has been based upon a consistent research method in twelve states.

Table 2 presents a comparison of the findings of our study with Morehouse's list of the most influential groups in each southern state a little more than a decade ago. ${ }^{5}$ Our list includes two paragraphs for each state: groups and interests in the first paragraph are those assessed as the most consistently influential in that state during the 1980s; the second paragraph includes 1) those assessed as rising in power but not yet among the first rank, 2) those whose once-considerable power was in decline during the $1980 \mathrm{~s}$, and 3 ) those that were influential but only intermittently active.

Several trends are discernible from a comparison of these two lists. One is that the days of "company states" run by one or two dominant interests -- the Bourbon planters, the "Big Mules" (coal, iron, steel, and utilities) in Alabama, the "Big Four" (oil, chemicals, railroads, and manufacturing) in Texas -- are virtually gone. Many still 


\section{Clive S. Thomas and Ronald J. Hrebenar}

TABLE 2. Most Effective Interest Groups in Twelve Southern States: An Alternative Assessment to Morehouse

Farm Bureau Federation; utilities; highway interests; Associated Industries of Alabama.
Transport; agriculture; utilities; natural resources (oil, timber, bauxite); insurance, local government (County Judges Association, Arkansas Municipal League), labor; Chamber of Commerce; Arkansas Free Enterprise Association.

Associated Industries; utilities (Florida Power Corp., Florida Power and Light); Farm Bureau, bankers; liquor interests; chain stores; race tracks; Phosphate Council.

\section{ALABAMA}

Al Education Association; Al Farmers' Fed (AFA); AL Cattlemen's Assn.; utilities (Al Power, South Central Bell; AL Gas Corp); private transportation (road-builders, concrete suppliers, car dealers, rail roads, gasoline suppliers); Business Council of $\mathrm{Al}$; Wholesale Beer and Wine Assn.; AL Retail Assn.

Commissioners; AL State Employees Assn.; attorneys (State Bar, Trial Lawyers, District Attorneys); AL Central Labor Council, AFLCIO; Black American Groups (esp. AL Democratic Conference, New South Coalition).

\section{ARKANSAS}

Utilities (AR Power and Light, ArkansasLouisiana Gas, electric coops); AR Ed. Assn.; Associated Industries of AR; banks and financial institutions; State Highway Commission; Governor's Office; Game and Fish Commission; AR Med. Assn.; Chamber of Commerce; AR Poultry Fed.

Railroads; AR Farm Bureau; timber and pulp companies; local govts; insurance industry; AFL$\mathrm{CIO}$; state employees; lawyers (trial lawyers, State Bar Assn.); religious lobbies (esp. Baptists); Common Cause.

\section{FLORIDA}

FL Assoc. of Realtors; Associated Industries; Trial Lawyers; FL Assoc. of Insurance; Governor's Office; school teachers (FTP/NEA, FL Education Assn.); Homebuilders and Contractors Assn.; Health groups (FL Medical Assn., FL Dental Assn., FL Hospital League).

Farm Bureau; FL Citrus Processors; Phosphate Council; banks and financial institutions (esp. Barnett Banks); liquor interests; FL Power Corp (utility); chain stores; race tracks; senior citizens; environmentalists; media groups; "Committee of 100 " (assn. of business and community leaders). 


\section{Interest Group Politics}

(Table 2 continued)

Atlanta business groups; Citizens and Southern Bank; Coca-Cola; Fuqua Industries; Delta Airlines; Trust Company of Georgia; Woodruff Foundation; Education lobby; Georgia Municipal Association.

Coal companies; Jockey Club; liquor interests; tobacco interests; Kentucky Eduction Association; rural electric cooperatives.

\section{GEORGLA}

Atlanta banks; business assns. (esp Business Council of GA); Med Assn. of GA; GA Assn. of Educators (school teachers); Dept.of Transportation; Coca-Cola; Delta Airlines.

State Board of Regents; GA Municipal Assn.; Assn. of County Commissioners; Trial Lawyers.

\section{KENTUCKY}

KY Ed. Assn; Farm Bureau; Chamber of Commerce: AFL-CIO and traditional unions; KY Bankers' Assn.; KY Med. Assn.; KY Utility Company; state universities.

KY Coal Assn; KY Retail Fed.; KY Hospital Assn.; Humana Hospitals; Associated Industries of KY: Horsemen's Benevolent and Protective Assn.; KY Thoroughbred Assn.; Prichard Group (a citizen education lobby); environmentalists (esp. Kentuckians for the Commonwealth).

\section{LOUISLANA}

LA Assn. of Business and Industry; LA AFL-CIO; oil and gas industry; LA Chemical Assn.; timber; wholesalers and retailers (esp. liquor and beverage companies); LA Assn. of Educators (and the K-12 lobby in general); banking industry.

Trial Lawyers; local govt. groups (esp. LA Municipal Assn., county commissioners); LA Farm Bureau; seafood industry, environmentalists; public interest groups (esp. Common Cause); legislative caucuses. 
(Table 2 continued)

Mississippi Economic Council; Farm Bureau; manufacturers' association; medical association; public school teachers; associations of local officials (county supervisors, mayors, sheriffs, etc.), segregationist groups (Citizens' Council, John Birch Society, Association for Preservation of the White Race, Women for Constitutional Government).

\section{MISSISSIPPI}

MS Assn. of Educators; MS Bankers' Assn.; MS Economic Council; utilities (esp. MS Valley Gas, MS Power and Light, South Central Bell); MS State Med. Assn.; state agencies (esp. Agriculture, Highway, Education and Public Welfare Depts.); State Employees' Assn. of MS; MS Manufacturers' Assn.

MS Farm Bureau; MS Trial Lawyers' Assn.; oil companies; insurance companies (esp. Alliance of American Insurers, Nationwide Insurance Co.); NAACP; MS Assn. of Supervisors; MS Muncipal Assn.; MS AFL-CIO; Common Cause.

\section{NORTH CAROLINA}

Textiles; tobacco; furniture; utilities; banks; teachers.

Education (esp. school teachers - NC Assn. of Educators); NC Bankers' Assn. and individual banks (esp. NCNB Corp. and Wachovia Bank); business organizations (esp. NC Citizens for Business and Industry); State Employees Assn. of NC; lawyers (NC Bar Assn., Academy of Trial Lawyers); NC Med. Soc.; Insurance; Agriculture (esp. NC Farm Bureau).

Local govt. lobby (esp. NC Assn. of County Commissioners); utilities; NC Beer Wholesalers' Assn., environmentalists (esp. the Conservation Council of NC); the State Council for Social Legislation; the Public School Forum of NC: the NC Center for Public Policy Research (private "think tank").

\section{SOUTH CAROLINA}

Planters; textiles (DuPont, Stevens, Deering-Milliken, Fiberglass, Textron Chemstrand, Lowenstein, Burlington, Bowaters); Electric and Gas Company, banks.
Banks; utilities (esp. SC Electric and Gas Co., Carolina Power and Light, Duke Power Co., Santee-Cooper, Electric Co-ops); textiles (esp. SC Textile Manufacturers' Assn.); real estate; construction; waste management.

Lawyers; Chamber of Commerce; health care (doctors, nurses, hospitals); school teachers; savings and loans; state universities and technical colleges; Governor's Office and state agencies; local govts. (counties and municipalities); timber/ paper; farm groups; environmentalists. 


\section{Interest Group Politics}

(Table 2 continued)

\section{TENNESSEE}

Manufacturers Association; County Services Association; Farm Bureau; Municipal League; Education Association; liquor lobby.
TN Farm Bureau; liquor lobby (Beverage Wholesalers, Malt Beverage Assn.); TN Bankers' Assn.; TN Ed. Assn; TN Automotive Assn.; TN Muncipal League; lawyers (Bar Assn. and Trial Lawyers); TN State Employees' Assn.

TN Manufacturers' Assn.; Taxpayers' Assn.; TN Med. Assn.; TN Business Roundtable; TN Health Care Assn.; Insurers of TN; TN Press Assn.; TN Road Builders' Assn.

\section{TEXAS}

Chemical Council; Mid-Continent Oil and Gas Association; Independent Producers and Royalty Owners; State Teachers' Association; Manufacturers' Association; Medical Association; Motor Transport Association; insurance organizations.

Virginia Electric Power; Virginia Manufacturers' Association; Chamber of Commerce; railroads.
TX Trial Lawyers' Assn.; TX Med. Soc.; TX Realtors' Assn.; TX State Teachers' Assn.; big oil (esp. MidContinent Oil and Gas Assn.).

TX Motor Truck Assn.; TX AFL-CIO; Independent Oil and Gas Producers Assn.; TX Chemical Council; TX Assn. of Business; TX Savings and Loan Assn.

\section{VIRGINLA}

Utilities (esp. Virginia Power); manufacturers (esp. VA Manufacturers Assn.); railroads (esp. Norfolk Southern, CSX); VA Bankers' Assn.; VA League of Savings Institutions; VA Retail/Merchants Assn.; builders and developers; VA Trucking Assn.; University of VA; VA Polytechnic Institute; VA Ed. Assn.

Chamber of Commerce; George Mason Univ.; James Madison Univ.; environmentalists; Amer. Civil Liberties Union.

Source: Sarah McCally Morehouse 1981: 108-111 printed with permission); Appendix A in Thomas and Hrebenar (1990). 
have an identifiable prime interest, such as the Farm Bureau in Tennessee or the oil companies in Texas and Louisiana, but these now must share power with other groups. Pluralism has replaced the days when one or two interests could impose their will across a wide range of issues. This decline of the dominion of a single interest has not meant, however, the decline of the dominance of the interest group system as a whole, as we shall see shortly.

Another trend is that three of the five interests prevalent in the South up until the early 1960s have maintained or enhanced their power, while two appear to have lost ground. Business, local governments, and education -- especially teachers' unions -- remain influential. Traditional labor unions, however, have experienced a decline of influence, and so has agriculture.

Contrary to some predictions, increased political pluralism and fragmentation within the business community does not appear to have affected its power significantly. To be sure, some businesses such as the railroads and the primary, extractive industries (e.g., bauxite mining in Arkansas, phosphate mining in Florida, and iron ore in Alabama) have declined drastically in production and influence in recent years; but these have been replaced among the ranks of the most powerful groups by newer, service-related businesses such as the leisure industry, trucking, real estate, and even retail chains. The power of business has been maintained, and in most southern states enhanced, by the South's new obsession with economic development. Economic development currently is the top priority in virtually every southern state, which advantages business considerably in the competition for access and influence. Consequently, business interests are probably stronger in southern state capitals than in any other region of the United States. This entrenched strength, in addition to being the major continuity of interest group politics in the South, is also a driving force behind the recent successes of other interests, such as the tax increases earmarked for education in Arkansas, Texas, and several other states during the 1980s.

On the other hand, agriculture and traditional labor appear to have suffered some loss of power relative to the other three traditional interests, even though they still rank among the most influential interests in some southern states. Outside of Louisiana, traditional labor has never been strong in the South, which is the least unionized region in the country (South and North Carolina, for example, rank 49th and 50 th, respectively, in percentage of unionized workers). Still, in the last 
ten to fifteen years, unionism has undergone a new phase in which the influence of teachers' and state and local employees' associations has surpassed that of the older, industrial trade unions. This rise parallels the growing activity of state government itself, and undoubtedly has both benefitted from and in turn contributed to the growing power of state agencies such as departments of education and state university systems. Such trends occurred throughout the country, and were not peculiar to the South alone.

The various components of the health care industry also have seen an increase in their power. Less significant, but steady gains have been made by environmentalists and by senior citizens. Certain singleissue groups, such as anti-ERA groups, anti-abortion groups, and Mothers Against Drunk Driving, have enjoyed success in several states. As in the rest of the states, the issue of tort reform (usually regarding caps on awards in damage suits) brought three of the best-financed and best-organized interests -- doctors, lawyers, and insurance companies -into the ranks of the most effective interests in the South during the 1980s.

The successes of other interests, including minority and social issue groups, were not sufficiently numerous in the South to emerge as trends. Non-economic interests probably fared worse in the South than in any other region of the country. Once again, we can trace this to the traditionalistic political culture, the continuing belief in laissez faire economics, and the strong strain of conservatism that still dominates the region.

Overall, the changes in the configuration of group power across the South (and in other states) have been less dramatic than the major expansion in group activity would lead us to assume. This is not surprising, when we consider the lingering influences of the southern tradition. But perhaps even more important are the factors that constitute individual group power. The players in the game may have multiplied by dint of the addition of new groups, but the rules of success, i.e., command of resources and build-up of long-term relationships with public officials, remain virtually unchanged.

Table 3 compares the most influential interests in the South with those in the other three regions and with the 50 states as a whole. Here we can see the greater power of certain economic interests in the South (viz., bankers' associations, lawyers, doctors, manufacturers, farm organizations, builders, and truckers), and the comparatively 


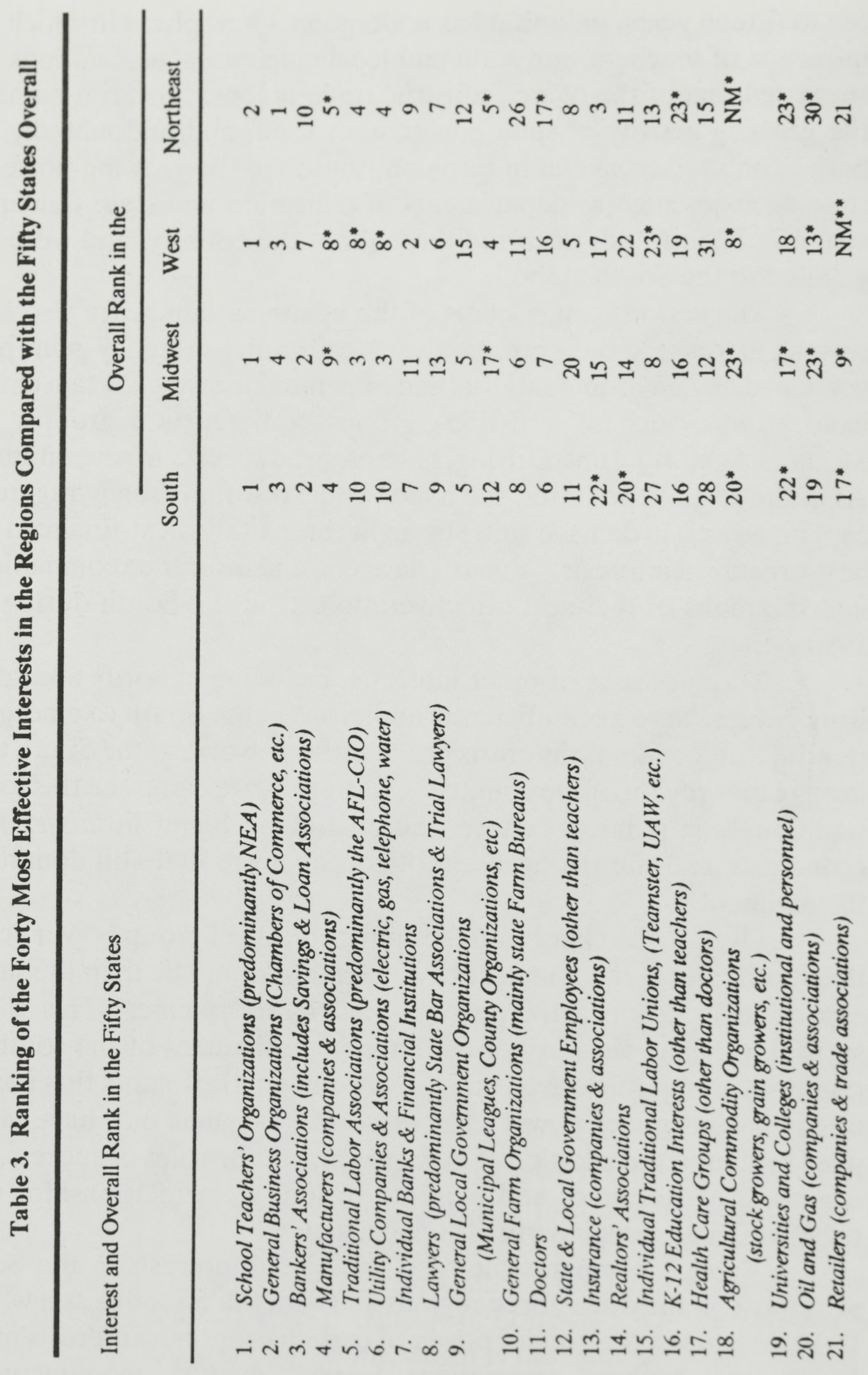




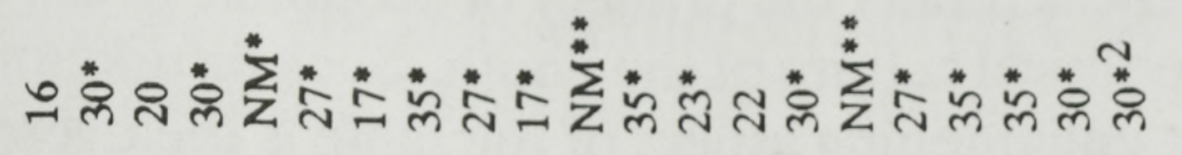

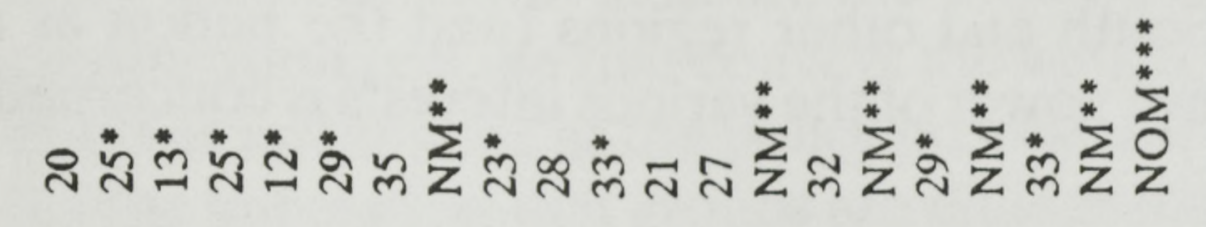

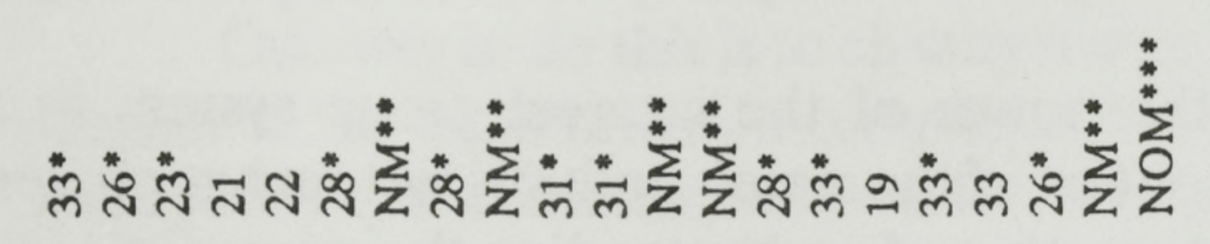

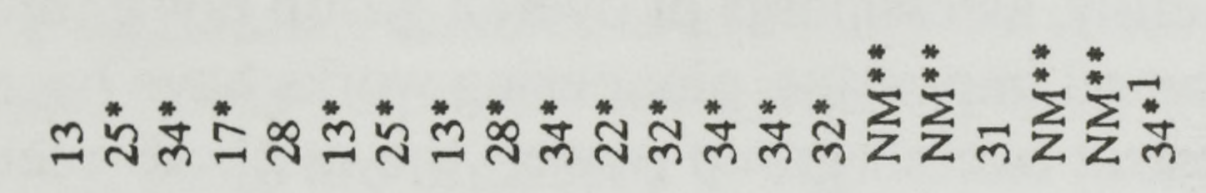

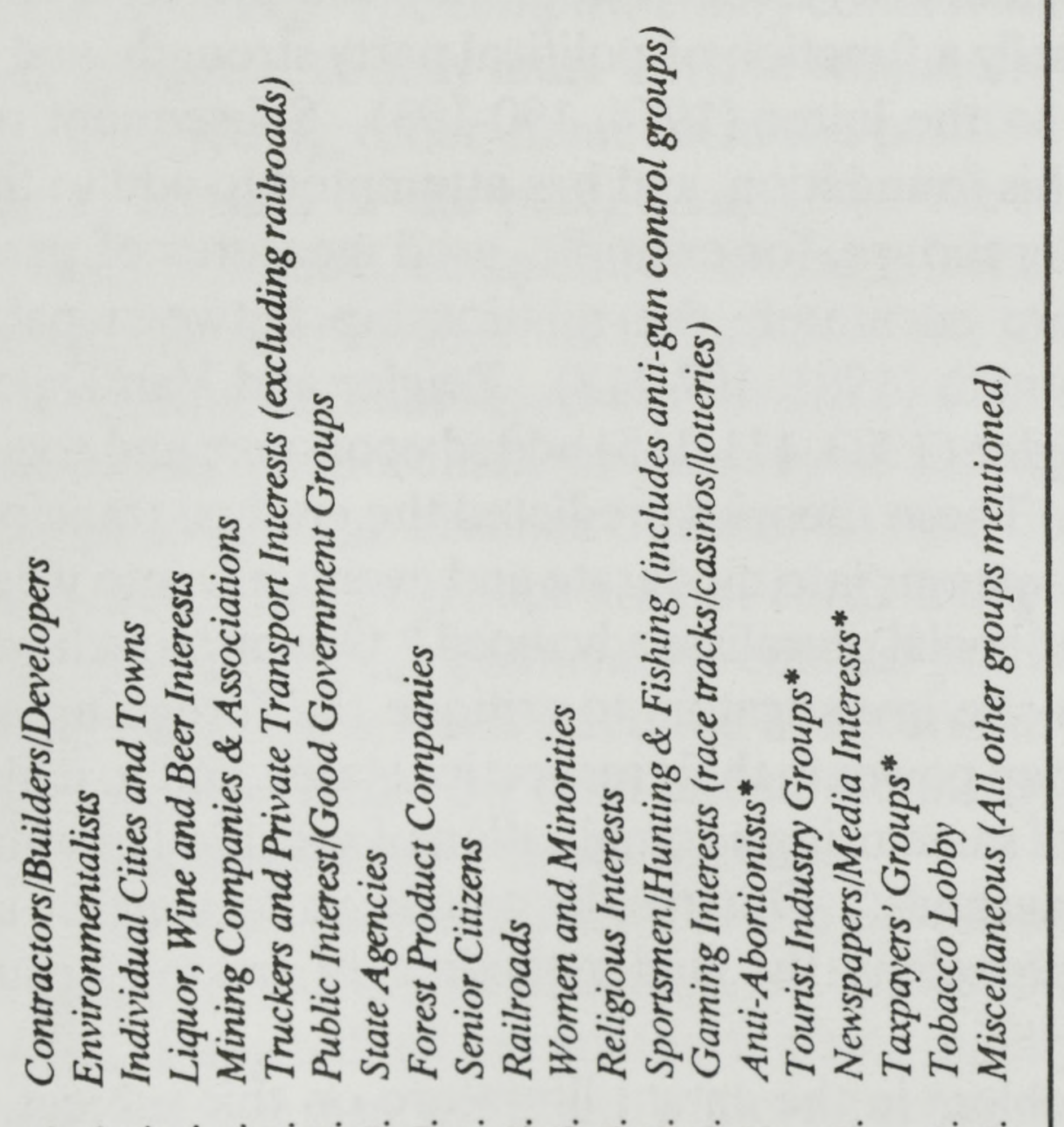

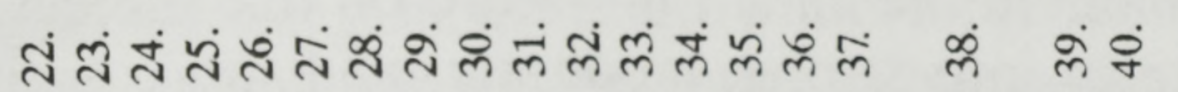

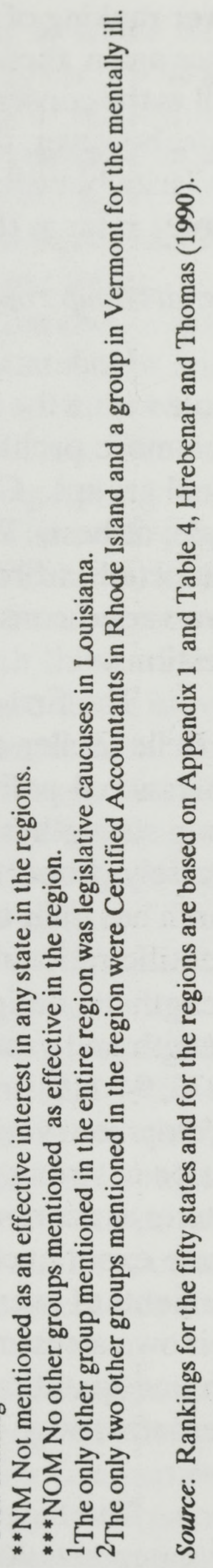


lower ranking of traditional labor, mining, and women and minorities. Once again, these differences reflect the primacy of economic goals, as well as the conservative political culture of the South. Such distinctions aside, however, the most enlightening aspect of the table is the overall similarity between the South and other regions (and the nation as a whole) as far as the relative power of the various interests is concerned.

\section{Overall Group Power}

Understanding the power of the interest group system as a whole within the larger context of the state's political system has proven even more problematic than that of understanding the power of individual groups. Consequently, assessments of overall group power are crude, at best. While several important, pioneering works have been conducted in order to assess overall group power, the methods used have varied considerably, and the results have left many unanswered questions.

The first attempt to assess overall group power was conducted by Belle Zeller (1954), and consisted entirely of the assessments of professional political scientists. Zeller established the principle that group strength is primarily a function of political party strength, and is inversely proportional to the latter (1954, 190-193). Subsequent research has built upon this foundation, and has attempted to add to the scientific rationale. Morehouse, for example, used measures of party strength to define more accurately the relationship between party strength and group strength (1981, 107-117). Zeigler and Van Dalen (1976, 94-110) and Zeigler (1983, 111-115) added economic and social development variables. These theories predicted the gradual transformation of strong group systems into moderate and eventually into weak systems as economic and social pluralism advanced. ${ }^{6}$ Our approach was to use experienced, on-site investigators to critique the foregoing assessments of overall group power in their respective states, and to make their own assessments of same using a combination of specified qualitative and quantitative methods. Our results enable us to suggest an alternative way of approaching the understanding of overall group power.

The biggest problem in the extant literature on this subject is the categorization of states into strong, moderate, and weak group systems. First, this typology leaves the mistaken impression that in some states, groups are literally weak or virtually powerless, and there- 
fore of little political significance. However, even in states where groups are not all-powerful, certain organizations may exert considerable influence, as do the UAW and the auto makers in Michigan. A more accurate way to measure the overall impact of groups is to use a classification scheme that conveys the weight of groups relative to that of other institutions in the policy processes of the states, without leaving the impression that groups are unimportant in some states.

One way to do this is to classify the group system on the basis of whether it has a dominant, a complementary, or a subordinate impact upon policy (or a combination of two of these) in relation to other elements of the system. The research gathered for the HrebenarThomas study enables us to classify the states according to their impact upon their respective state policy making systems. The results for all fifty states are organized by region and presented in Table 4, in order that the interest group systems of the South may be understood in comparison with those of the other regions, and with those of the 50 states in toto. States listed in the dominant column are those in which groups as a whole are the consistent and overwhelming influence upon policy making. The complementary column contains those states where groups either usually must work in conjunction with, or are frequently constrained by, other elements of the political system. Most often the latter consists of the party system, but the political culture, a strong executive branch, competition among groups, or some combination of these may also balance the influence of the interest group system. The subordinate column represents a situation in which the group system is consistently subordinate to other elements involved in the policy making process. The absence of states in this column reflects that, in this research, interest groups are not consistently subordinate in any state. The dominant/complementary column includes those states whose interest group systems fluctuate between the two situations, or are in the process of moving from one to the other. The same holds for the complementary/subordinate column.

With the exception of North Carolina, all of the southern states appear in either the dominant or the dominant/complementary column. Fully half of the southern states qualify for the dominant category. As a region, the South's interest group systems are unsurpassed in their overall impact upon state public policy. The West comes closest to the South in this regard, and not very close at that. Thus, despite many changes in southern life and politics in recent times, these have not markedly affected the overall power of interest groups. Indeed, in 


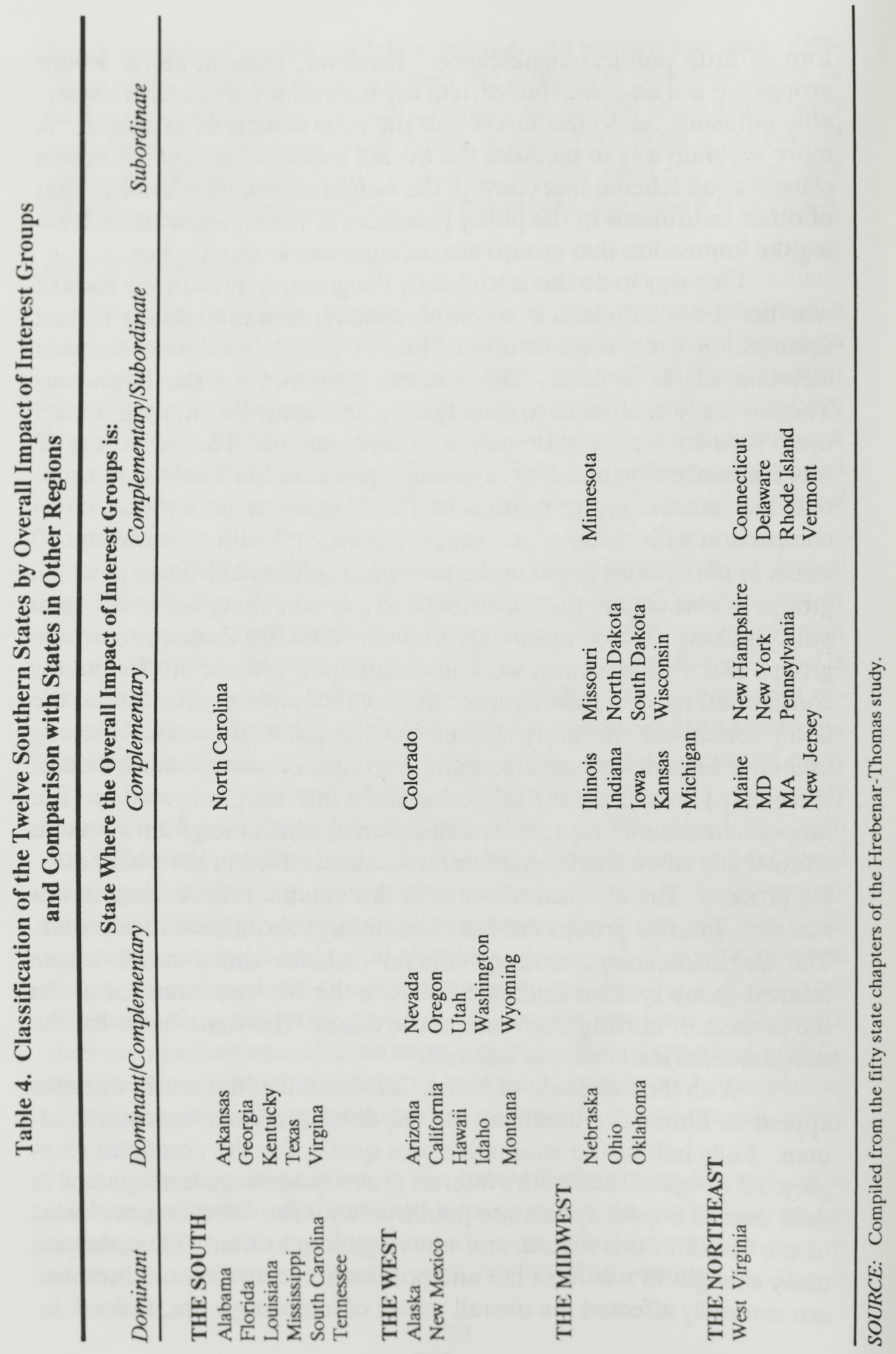


several southern states (e.g., South Carolina, Georgia, Florida, and Kentucky), interest groups are perhaps more powerful than ever, both individually and in their overall impact on state politics.

This classification system was developed after the research was completed and we had assessed the results concerning overall group power in all 50 states. With the largest volume of research ever gathered on this topic at our disposal, we have been able to question some previously held dogmas about overall group power in the states. First, the inverse relationship between party strength and group impact does not always hold; and socioeconomic development and increased professionalism in government does not always lessen the impact of groups on a state's political system. This is not to say that these variables are insignificant. Rather, it is to say that their effect upon overall group power is not always that which earlier formulations have predicted. For instance, it is generally true that party strength has considerable influence upon the overall impact of groups. However, although weak party systems are invariably accompanied by dominant group systems, strong parties do not always result in weak interest group systems, as Illinois and New York attest; and increasing party strength may not lessen overall group influence, as recent politics in California demonstrate. Similarly, the dominance of groups in the contemporary South testifies that socioeconomic development and professionalization do not always have the effect of balancing interest group strength.

Consequently, a key finding is that there is no automatic progression from dominant to subordinate status for groups as socioeconomic development and/or political professionalization occur. In fact, the opposite may occur. All this leads us to conclude that party strength, political professionalism, and socioeconomic development are not the only variables that influence overall group power, and in some circumstances may not even be the most important variables. A more extensive explanation is needed. While we do not claim to have developed a definitive theory, a more comprehensive understanding is provided by the components of our analytical framework presented above.

Each of the eight factors in this framework has some influence upon overall group power. However, the impact of each varies from state to state, and from time to time within a state, and thus the combined influence of all eight factors varies accordingly. For example, the moralistic political culture in North Dakota apparently moderates 
group influence in a context otherwise tailor-made for interest group dominance: relatively weak parties, and a fragmented policy-making system that facilitates multiple access. In contrast, the same political culture does not similarly restrain group power in Oregon. There, multiple access in a fragmented system and the needs of economic development appear to be the most significant influences. As is true in the South, a particular policy preference such as economic development has worked to offset the influence of increased group competition that in other circumstances might have reduced the overall impact of groups.

\section{Interest Group Tactics and Lobbyists in the South}

In the South, as elsewhere, the use of political power by railroad interests during the late nineteenth century contributed to a legacy of public distrust of interest groups, and particularly of the lobbyists who represent them. Over the years this attitude was reinforced as groups, realizing the importance of governmental action and inaction to their goals, proved willing to use almost any means at their disposal -- sometimes including illegal ones -- to secure access to public officials and to influence government decisions. The spread of populism, with its opposition to vested special interests, also contributed to southerners' popular disdain of interest groups. Yet, although these negative images live on, the passage of public disclosure laws and a general increase in public awareness over the past twenty-five years has changed the way that groups and lobbyists do business.

By far the most common and still the most effective tactic is the use of one or more lobbyists. Until very recently, this was the only tactic used by the vast majority of groups in the South, and it remains the sole approach used by many groups even today. Overall, the lobbying community in state capitals has become much more pluralistic and has increased its level of professionalism during the last two decades. Figure 2 depicts the make-up of the contemporary lobbying community in the twelve southern states. Contract lobbying appears to have made the greatest strides in professionalism; however, in-house lobbyists, particularly those representing associations, have also made such advances. While the level of professionalism varies from state to state, its general increase among contract lobbyists is evidenced by several developments, such as an increase in the number employed full-time, the emergence of lobbying firms that provide a variety of services and 
FIGURE 2.

The Five Categories of Lobbyists, Their Recruitment, Gender, and Approximate Percentage of the Capital Lobbying Community in Southern States

\section{Contract Lobbyists:}

Those hired on contract for a fee specifically to lobby. They often represent more than one client. Approximately $10 \%$ represent five or more clients.

Recruitment: Many, especially the most successful, are former elected or appointed state officials, usually legislators or political appointees, and sometimes former legislative staffers. An increasing number are attorneys from capital law firms or public relations and media specialists. Some are former in-house lobbyists. Few are former career bureaucrats.

Gender: Predominantly male, ranges from $85-95 \%$. This compares with $80-90 \%$ for the fifty states as a whole.

Percentage: Make up from $15-25 \%$ of the state capital lobbying community. This is about the same as the average for the fifty states.

\section{In-house Lobbyists:}

Employees of an association, organization or business, who as part or all of their job act as a lobbyist. These represent only one client--their employer.

Recruitment: Most have experience in the profession, business, or trade which they represent, e.g. education, health care, oil and gas, retailing, labor union activities. Much less likely than contract lobbyists to have been public officials; though more likely to have been so in southern states.

Gender: Approximately $80 \%$ male; $20 \%$ female; compared with a $75 \%$ male, $25 \%$ female average for all fifty states.

\section{Government Lobbyists and Legislative Liaisons:}

Employees of state, local, and federal agencies whose job is (partially or full-time) to represent their agency to the legislative and executive branches of state government. These represent only one interest. Includes state agency heads and senior staff, elected and appointed officials of local governments, and some federal officials.

Recruitment: Legislative liaisons are often career bureaucrats with broad experience in the agency or government unit that they represent. Some are political appointees and an increasing number are recruited from the ranks of legislative staffers. No common recruitment pattern exists for government lobbyists as a whole.

Gender: Approximately 25-35\% of legislative liaisons are female; higher in more economically and socially diverse states. Tends to be lower in the South, but exact figures are difficult to acquire as many states do not require government personnel to register as lobbyists. 
(Figure 2 continued)

Percentage: Difficult to estimate because they are often exempted from registering. A rough estimate for all government lobbyists is between $25-40 \%$. Tends to be higher in states where state and local government employment is highest, especially in the West. No exact figures are available for the South.

\section{Citizen or Volunteer Lobbyists:}

Persons who, usually on an ad hoc and unpaid basis, represent citizen and community organizations or informal groups. They rarely represent more than one interest at a time.

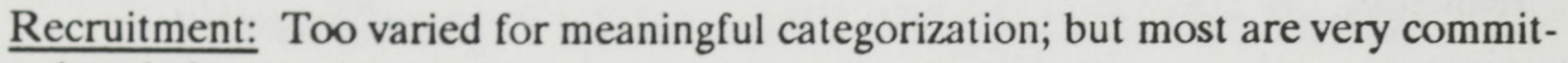
ted to their cause.

Gender: Difficult to estimate as many are not required to register as lobbyists. It appears that the majority (in some states as high as $75 \%$ ) are female.

Percentage: An estimate is from $10-20 \%$ of the state capital lobbying community in the states as a whole. Probably less in the South because social service/public interest groups are less numerous.

\section{Private Individual, "Hobbyist" or Self-Styled Lobbyists:}

Those acting on their own behalf and not designated by any organization as an official representative. They usually lobby for pet projects or direct personal benefits; or against some policy or proposal that they find particularly objectionable.

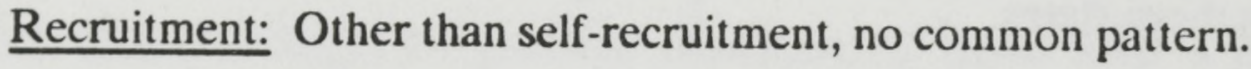

Gender: Difficult to estimate as many are not required to, or do not register as lobbyists. Most are probably male, especially in the South.

Percentage: Difficult to estimate, but probably less than 5\%. Maybe higher in the South due to the personalized and formerly elitist nature of politics.

Sounce: Adapted for the South from Figure 2 in Thomas and Hrebenar (1990, 150-151).

represent as many as twenty-five clients, and the increased specialization of many contract lobbyists as government itself has become more complex and specialized.

In the raw, the good ol' boy lobbyists and their wheeler-dealer methods have all but disappeared from southern state capitals. However, most successful lobbyists today remain to some degree wheelerdealers underneath a more sophisticated guise. Like their predecessors, they realize the need for a multi-faceted approach to establishing and maintaining good relations with public officials. This includes 
everything from participating in election campaigns to helping officials with their personal needs. But more than this, the modern lobbyist is very aware of the increased importance of technical information, of the increased professionalism and changing needs of public officials, and of the increased public visibility of lobbying. The result is a low-key, highly skilled and effective professional that is a far cry from the old stereotype.

Another aspect of continuity in southern interest group politics is that despite the increased professionalism and expansion of both the lobbying community and state government, personal contacts and long term relationships between lobbyists and policy-makers remain major ingredients of success. This is true in all states, but doubly true in the South, with its long tradition of personalized politics undiminished by strong parties or by strong executive or legislative leadership.

Since the 1960s, increased competition among groups, the changing needs of public officials, and increased awareness of the activities of interest groups have spawned other tactics to support the work of the lobbyist. These include mobilizing grassroots support through networking (sophisticated, computerized member contact systems), public relations and media campaigns, building coalitions with other groups, and contributing workers and money to election campaigns, particularly by establishing a PAC. But such tactics are not viewed as substitutes for lobbying. Rather, they are employed as means of enhancing the access of the group's lobbyists to public officials. Group leaders choose the most cost-effective method of achieving their goals. In most cases, this means establishing a legislator-lobbyist contact that involves a minimum of other group members. They employ the new, additional techniques only if and when necessary. This is in part because such networks, public relations campaigns, and electioneering are all very costly. Equally important is the consideration that the more complex the strategy and the more people there are involved in it, the harder it is for the group's leaders and lobbyists to orchestrate. Nevertheless, for the reasons given earlier, these new direct and indirect techniques of influence are gaining wider and increased use.

\section{Conclusions}

As with most aspects of its politics, the South's interest group system and its politics are both similar and different when compared to the nonsouthern states. On the one hand, there are not any features of 
interest group activity in these states that are either strictly or characteristically southern. Although there certainly are variations between these twelve and the other 38 states, such variations frequently derive from circumstances that are not indigenous or unique to the region, or are found to occur within the South itself. As in any region, it is the state's level of socioeconomic and political development that is the primary determinant shaping its interest group system. Florida's interest group system, for example, is far more akin to those of the populous and economically and socially diverse states of the Northeast and Midwest than to those of Arkansas or Alabama. Similarly, certain intraregional differences that exist between the peripheral southern states (Arkansas, Kentucky, Tennessee) and the Deep South states can be ascribed to the differences in their respective economies and their social make-up. Finally, it must not be forgotten that developments since the 1960s have tended to reduce differences among the political systems of the fifty states as the latter become more and more like their counterpart in Washington, D.C.

Nevertheless, despite some intraregional differences and extraregional similarities, the South's interest group system does manifest certain common characteristics, some of which set it apart from the rest of the nation. These stem primarily from the nature of the southern historical experience and from the South's current preoccupation with economic development, plus its perception that it needs to catch up with the rest of the nation in areas such as education. There are also the South's relatively weak political institutions (especially its parties and governors), its populist tradition, its strong conservatism, and its relatively low level of government professionalism. The result has been that southern interest group systems as a whole have been, and remain, very powerful. In this last regard, they are unsurpassed by those of any other region.

To be sure, some major changes within the southern interest group system have occurred during the past three decades. Federal voting rights legislation has resulted in increased political participation among individuals and groups not previously represented. This increased participation, together with economic development and diversification, has resulted in an increase in the range of interest groups operating in southern capitals and in commensurate demand for government services and benefits. The resulting competition among groups has prompted not only the decline of certain interests traditionally strong in southern capitals (agriculture, traditional labor), but also a 
marked increase in the professionalism of lobbyists and their methods.

Still, although these changes have resulted in an increase in the number of people represented within the group system, and in the alteration of its style and tactics, such developments are outweighed in import by the continuities of the interest group system that have survived intact. The crucial resources of influence--substantive expertise, interpersonal skills, and (most of all) money for lobbying, media campaigns, networking, and campaign contributions--are still more easily available to business, professional groups, and government agencies than to other kinds of groups. Such advantages enable the traditional, entrenched economic and institutional interests to continue to exert the most consistent influence upon public policy in the South. The result is that the transformations of southern politics that have taken place recently have effected pro forma pluralism, but not de facto pluralism, in the most interest group-dominated state political systems in America. This belies and necessitates the rethinking of existing theory about the presumedly inverse relationship between socioeconomic development, party system development, and governmental professionalization, on the one hand, and the degree to which interest group power will dominate state governments' policy processes, on the other.

\section{NO'TES}

${ }^{1}$ For more on this framework, see chapters 1 and 14 of Hrebenar and Thomas, Interest Group Politics in the Southern States (Tuscaloosa, AL: University of Alabama Pess, forthcoming 1992).

${ }^{2}$ This study took six years to complete and involved 78 political scientists who performed the state-specific studies. Among the publications yielded by this study thus far are Hrebenar and Thomas 1987, 1990, 1992a and 1992b, in addition to the present study.

${ }^{3}$ The investigators of these studies of the southern states were David L. Martin (Alabama), Arthur English and John J. Carroll (Arkansas), Anne E. Kelley and Ella L. Taylor (Florida), Eleanor C. Main, Lee Epstein, and Debra L. Elovich (Georgia), Malcolm E. Jewell and Penny M. Miller (Kentucky), Charles J. Barrilleaux and Charles D. Hadley (Louisiana), Thomas H. Handy (Mississippi), Jack D. Fleer (North Carolina), Robert E. Botsch (South Carolina), David H. Folz and Patricia K. Freeman (Tennessee), Keith E. Hamm and Charles W. Wiggins (Texas), and John T. Whelan (Virginia).

${ }^{4}$ Two-thirds of the researchers used these common survey instruments or some derivation of them. 


\section{Interest Group Politics}

${ }^{5}$ Morehouse's list (1981: 108-112) was based largely on secondary sources, and particularly on Neal R. Peirce's series of books on the regions of the U.S. A slightly updated version of Morehouse's table based mostly upon Peirce and Hagstrom's The Book of America: Inside the Fifty States Today (1983) is found in Engel (1985): 241-242.

${ }^{6}$ Two other studies have attempted to assess overall group power in the fifty states to some degree. Each, however, based their assessment upon a selective, limited segment segment of the policy-making process. Francis (1967) examined group power only as regards the state legislatures; and Abney and Lauth (1986) based their assessment on a survey limited to administrators.

\section{REFERENCES}

Abney, Glen and Thomas P. Lauth. 1986. Interest Group Influence in the States: A View of Subsystem Politics. Paper delivered at annual meeting of the American Political Science Association, Washington, DC.

Ball, Howard, Dale Krane, and Thomas P. Lauth. 1982. Compromised Compliance: Implementation of the 1965 Voting Rights Act. Westport, CN: Greenwood.

Black, Earl and Merle Black. 1987. Politics and Society in the South. Boston: Harvard University Press.

Blair, Diane D. 1988. Arkansas Politics and Government. Lincoln, NE: University of Nebraska Press.

Bass, Jack and Walter DeVries. 1976. The Transformation of Southern Politics. NewYork: Basic Books.

Bell, Charles G., Keith E. Hamm, and Charles W. Wiggins. 1985. The Pluralistic Model Reconsidered: A Comparative Analysis of Interest Group Policy Involvement in Three States. Paper delivered at annual meeting of the American Political Science Association, New Orleans, LA.

Bentley, Arthur. 1908. The Process of Government. Chicago: University of Chicago Press.

Dunn, Charles DeWitt and Donald E. Whistler. 1987. Professional and Amateur Lobbyists in the Arkansas General Assembly. Arkansas Political Science Journal 8: 27-40.

Engel, Michael. 1985. State and Local Politics. New York: St. Martin's Press.

Francis, Wayne L. 1967. Legislative Issues in the Fifty States. Chicago: Rand McNally and Co.

Havard, William C., ed. 1972. The Changing Politics of the South. Baton Rouge: Louisiana State University Press.

Hrebenar, Ronald J. and Clive S. Thomas, eds. 1987. Interest Group Politics in the American West. Salt Lake City: University of Utah Press. , eds. 1992a. Interest Group Politics in the Midwestern States. Ames, IA: Iowa State University Press. ,eds. 1992b. Interest Group Politics in the Southern States. Tuscaloosa, AL: University of Alabama Press.

Kelley, Anne E. and Ella L. Taylor. 1992. Florida: The Changing Patterns of Power. In Ronald J. Hrebenar and Clive S. Thomas, eds., Interest Group Politics in the Southern States. Tuscaloosa, AL: University of Alabama Press. 